\title{
Spectroscopic study of inclusions in gem corundum from Mercaderes, Cauca, Colombia
}

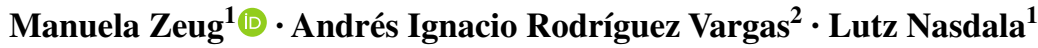

Received: 29 February 2016 / Accepted: 10 October 2016 / Published online: 19 October 2016

(C) The Author(s) 2016. This article is published with open access at Springerlink.com

\begin{abstract}
Mineral inclusions in gem corundum from Mercaderes, Cauca, Colombia, were investigated non-destructively using Raman and photoluminescence spectroscopy, with special focus lying on phases containing radioactive elements. Besides abundant rutile, the minerals zircon, apatite, feldspar, and an epidote-group species, most probably allanite-(Ce), were found. The latter is detected easily from its characteristic $\mathrm{Nd}^{3+}$ emission pattern, which may prove useful in future provenance studies. Zircon inclusions range from well crystalline to moderately radiation damaged [FWHM (full width at half band maximum) of the $v_{3}\left(\mathrm{SiO}_{4}\right)$ Raman band $1.8-10.9 \mathrm{~cm}^{-1}$. Both the zircon inclusions and their neighbouring host corundum are affected by compressive stress, which is assigned to (1) heterogeneous volume expansion of the host-inclusion couple upon pressure release during the uplift following primary growth and (2) volume expansion of the zircon inclusion due to the accumulation of self-irradiation damage. Internal stress of zircon inclusions averages $~ 1.1 \mathrm{GPa}$. Heat treatment of corundum leads to structural reconstitution of zircon (narrowed zircon Raman bands with FWHMs in the range $1.8-2.7 \mathrm{~cm}^{-1}$ ) and accompanying stress release in the adjacent corundum (indicated by downshifts of the $R_{1}$ emission of $\mathrm{Cr}^{3+}$ ). The observation of broadened Raman band of zircon inclusions therefore allows one to exclude high-temperature enhancement of the host corundum.
\end{abstract}

Manuela Zeug

manuela.zeug@univie.ac.at

1 Institut für Mineralogie und Kristallographie, Universität Wien, Althanstr. 14, 1090 Vienna, Austria

2 Minerlab Limitada, Calle 51 Sur No 80i-34, Bogotá, D.C., Colombia
Keywords Colombian corundum · Zircon inclusion · Compressive stress/strain · Raman spectroscopy · Photoluminescence mapping

\section{Introduction}

Raman microspectroscopy is a long-established analytical method in inclusion studies, as it provides the opportunity to determine and investigate reliably solid (e.g. Smith 1984; Liu et al. 1990; Wopenka and Pasteris 1993; Ye et al. 2001; Gillet et al. 2002; Pearson et al. 2014) or fluid inclusions (e.g. Rosasco et al. 1975; Wopenka and Pasteris 1986; Dubessy et al. 1989; van den Kerkhof and Olsen 1990; Burke 2001; Rankin 2005). In many cases analyses are possible without special preparation needs. The Raman technique analysis has become, as a matter of course, particularly important in cases when facetted and/or mounted corundum $\left(\mathrm{Al}_{2} \mathrm{O}_{3}\right)$ and other gemstones are to be studied in a strictly non-destructive manner (Fritsch et al. 2012; see also Kiefert et al. 2001; Pinet et al. 1992; Bersani and Lottici 2010). In analysing zircon $\left(\mathrm{ZrSiO}_{4}\right)$ inclusions inside such gem-corundum specimens, Raman and also photoluminescence (PL) spectroscopy are excellent methods to gain additional information such as (1) estimates of the degree of radiation damage in zircon crystals confined within a host corundum, (2) determination of pressures acting on such inclusions, and (3) hints to the provenance assignment of gems of unknown origin (Wanthanachaisaeng et al. 2006; Wang et al. 2006; Wanthanachaisaeng 2007; Noguchi et al. 2013).

Zircon typically incorporates trace amounts of the actinide elements $\mathrm{U}$ and $\mathrm{Th}$, which may substitute $\mathrm{Zr}^{4+}$ at the eightfold lattice site. Over geologic periods of time, this mineral undergoes a gradual process of structural 
destruction, which is mainly due to corpuscular self-irradiation resulting from alpha-decay events in the decay chains of ${ }^{238} \mathrm{U},{ }^{235} \mathrm{U}$, and ${ }^{232} \mathrm{Th}$ (e.g. Weber et al. 1994). The progressive accumulation of radiation damage will eventually lead to an amorphous, "metamict" state (e.g. Ewing et al. 1987; Ewing 1994; Meldrum et al. 1999). Damage is created mainly by recoils of heavy nuclei (energies 0.06$0.17 \mathrm{MeV}$ ) upon emission of alpha particles (energies 3.98.8 MeV; cf. Nasdala et al. 2001); these recoils produce tiny amorphous clusters (Weber et al. 1994; Trachenko et al. 2002; Devanathan et al. 2006). The accumulation of self-irradiation damage in zircon hence leads to (1) an increasing amorphous volume fraction and (2) increasingly irregular atomic positions and bond lengths in the remaining crystalline volume fraction.

The latter results in increasingly irregular vibrational frequencies of inter-atomic bonds, which is observed from increased widths of Raman bands assigned to the remnant crystalline fraction (Nasdala et al. 1995). The accompanying downshift of Raman bands is assigned to the general structural expansion and lengthening of bond distances in the disordered structure, additionally affected by the fact that an increase of the amorphous volume fraction must cause tensile stress in the crystalline remnants. It has been found that the band broadening [increase of FWHM (full width at half band maximum)] of the anti-symmetric stretching vibration of the isolated $\mathrm{SiO}_{4}$ tetrahedrons in the zircon structure $\left[v_{3}\left(\mathrm{SiO}_{4}\right)\right.$ Raman band near $1000 \mathrm{~cm}^{-1} ; \mathrm{B}_{1 \mathrm{~g}}$ mode; Dawson et al. 1971] is most sensitive to the accumulation of radiation damage (Nasdala et al. 1995). This parameter allows one to estimate the degree of structural damage; it increases from $<2 \mathrm{~cm}^{-1}$ for well-crystallised zircon to $>30 \mathrm{~cm}^{-1}$ for severely damaged samples (Zhang et al. 2000a; Nasdala et al. 2001). Recently Lenz et al. (2013) and Lenz and Nasdala (2015) have proposed to apply alternatively the FWHMs of certain REE (rare-earth element)-related PL emissions, especially of $\mathrm{Dy}^{3+}$ and $\mathrm{Nd}^{3+}$, to estimate the degree of radiation damage in zircon.

The gradual crystalline-to-amorphous transition of zircon has tremendous effects on the physical and chemical properties of this mineral (e.g. Holland and Gottfried 1955; Murakami et al. 1991). Among others, the accumulation of alpha-event damage leads to general volume expansion. In the case of chemically zoned zircon, heterogeneous selfirradiation and hence heterogeneous volume expansion may cause tensile stress in less radiation-damaged growth zones adjacent to more damaged zones (Lee and Tromp 1995; Nasdala et al. 2010). If U- and Th-bearing zircon is included within a non-U- and Th-bearing host mineral, volume expansion of the damaged zircon is hindered by the host, eventually resulting in compressive stress acting on the zircon inclusion. Compressive stress acting on a zircon inclusion may result alternatively from entrapment of an inclusion at elevated depths below the Earth surface and heterogeneous volume expansion of the host-inclusion couple upon pressure release during uplift from a deep formation milieu to the Earth surface (Parkinson and Katayama 1999; Kouketsu et al. 2014; Zhukov and Korsakov 2015). Such compressive stress is occasionally referred to as "fossilised pressure" (Sobolev et al. 2000; Lin et al. 2004).

In the present paper, we have done an in situ study of stress of zircon inclusions in alluvial gem corundum originating from Mercaderes, Cauca, Colombia. The formation of the Colombian corundum is still under debate, and their parent rocks are still unknown (Duroc-Danner 2002). There exist three different models, including (1) deep (i.e. lower crust or even mantle) magmatic corundum formation and subsequent uplift as xenocrysts in alkali basalts, (2) formation in metamorphic rocks that were then ejected as volcanic bombs, or (3) a combination of the two formations above, which would imply coexistence of two different genetic types of corundum (Romero and Rodríguez-Vargas 2002; Duroc-Danner 2002; Peucat et al. 2007). The presence of paragenetic minerals such as kyanite and hercynite seems to favour corundum formation in old metamorphic rocks (Romero and Rodríguez-Vargas 2002).

Our study aimed first at identifying the inclusions in the Mercaderes corundum based on their Raman and PL spectra. Second, special emphasis lied on the characterisation of the structural state (i.e. degree of radiation damage) of zircon inclusions, possible effects of stress, and potential conclusions on the samples' post-growth thermal history.

\section{Samples and experiments}

We have investigated seven corundum crystals from alluvial sands from the La Honda Creek placer deposit near the village of Mercaderes, Cauca State, southwestern Colombia. The placer is located north of the Río Mayo river, which in the study area forms the borderline between the Cauca department in the north and Nariño department in the south (Fig. 1). The Corundum mined here mainly originates from garnet-bearing tuffs (Romero and RodríguezVargas 2002; see area highlighted light red in Fig. 1). The corundum samples generally show greyish to pale blue colour, which may vary from plain blue-grey with brownish streaks and yellowish domains to pale bluish grey with a pink hue and pale pink (Fig. 2a). The weights of the corundum specimens studied here ranged from 0.7 to 4.25 carats $(0.14-0.85 \mathrm{~g})$. In six of the corundum samples, solid inclusions were clearly visible to the naked eye (Fig. 2b-e), whereas the seventh sample was found to be free of notable inclusions; it was therefore disregarded in the present study. Corundum crystals showed mechanical abrasion and corrosion features on their surfaces that cause loss of 


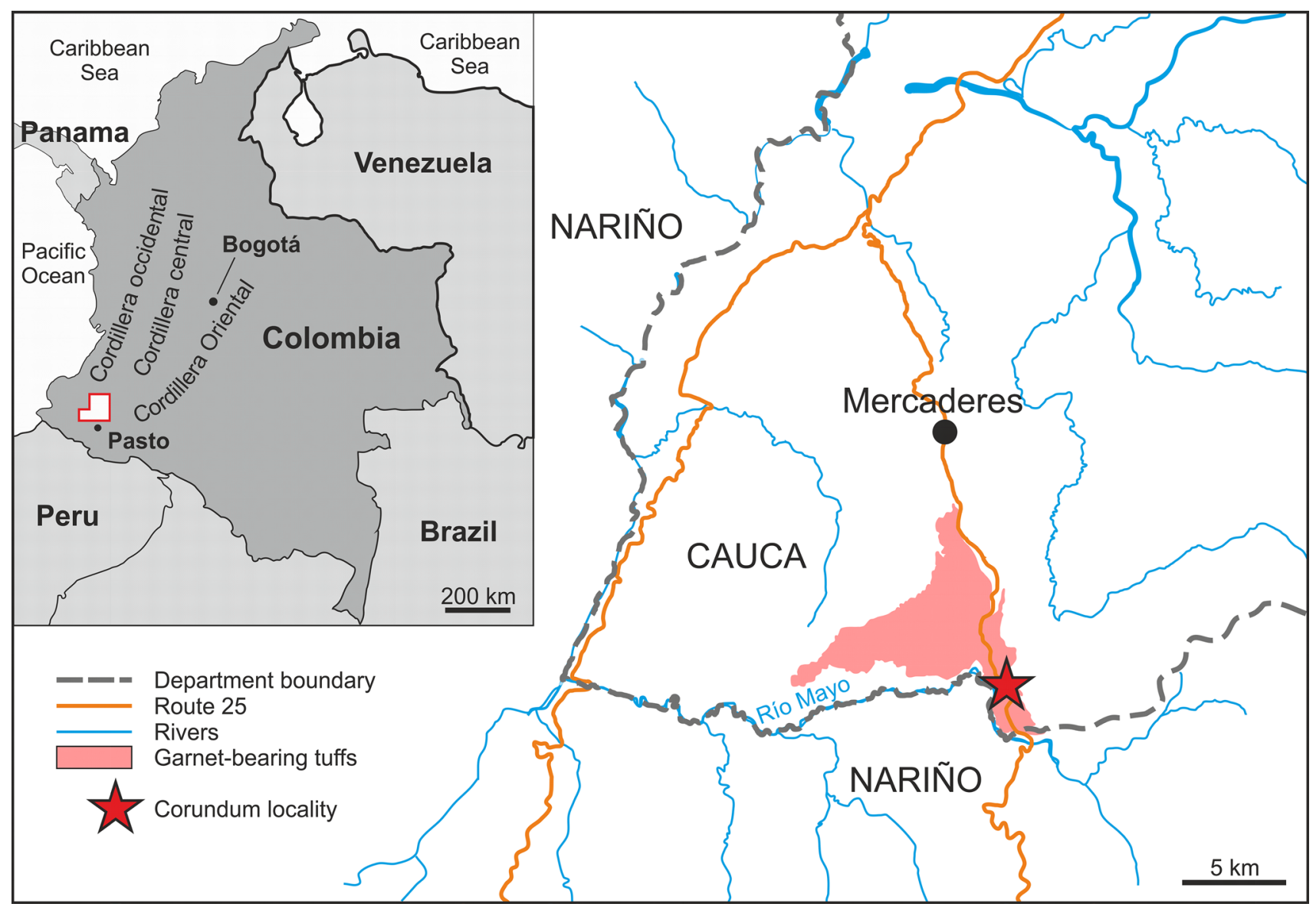

Fig. 1 Simplified map of the Mercaderes municipality (Cauca Department) in the Cordilleras, southwest Colombia, showing the location of origin (La Honda Creek) of the corundum samples studied

transparency (Fig. 2a); these are assigned to the mechanical transportation in the river.

Corundum specimens were cut, and in plane-parallel, doubly polished sections (thicknesses ca. 1-2 mm) were produced. For single-crystal X-ray diffraction and EDS (energy-dispersive X-ray spectroscopy) chemical analysis in an SEM (scanning electron microscope), a few fragments of epidote-group mineral inclusions were mechanically extracted from their host corundum sample. For SEM analysis, fragments were attached to an $\mathrm{Al}$ sample holder and coated with carbon to avoid charging effects.

One corundum specimen was subjected to heat treatment in air at 800,1000 and $1200{ }^{\circ} \mathrm{C}$, in order to characterise the behaviour of the zircon inclusions and their host upon thermal annealing. This sample was placed in an alumina crucible and heated up to the desired temperature at rate of $30 \% \mathrm{~min}$. At the end of the $24-\mathrm{h}$ run, the furnace was switched off. Only after another $6 \mathrm{~h}$, when the temperature had decreased to less than $100{ }^{\circ} \mathrm{C}$, the furnace door was slightly opened and the crucible lid was removed, to increase cooling speed down to room temperature. Spectra and PL maps were obtained after each individual heat treatment, and the same sample was then heated again.

Raman and PL measurements were taken at room temperature by means of two dispersive Horiba (Jobin Yvon) LabRAM HR800 and LabRAM HR Evolution spectrometers. Both systems were equipped with Olympus BXseries optical microscope, a grating with 1800 grooves per millimetre, and a Si-based, Peltier-cooled charge-coupled device (CCD) detector. Spectra were excited with the 785-nm emission of a diode laser (Raman) or the 473-nm emission of a diode-pumped solid-state laser (Raman, PL). These excitations were chosen to avoid analytical artefacts due to Raman bands possibly being obscured by intense laser-induced PL (for an extensive discussion see Nasdala et al. 2012). Laser energies were in the range $3-8 \mathrm{~mW}$ at the sample surface, which was well below the threshold of absorption-induced sample up-heating or degradation. Analyses of, and near, shallow inclusions, i.e. located less than $200 \mu \mathrm{m}$ below the polished sample surface, were obtained using an Olympus $100 \times$ objective (numerical aperture $=0.9$, free working distance $\sim 240 \mu \mathrm{m}$ ). Inclusions 


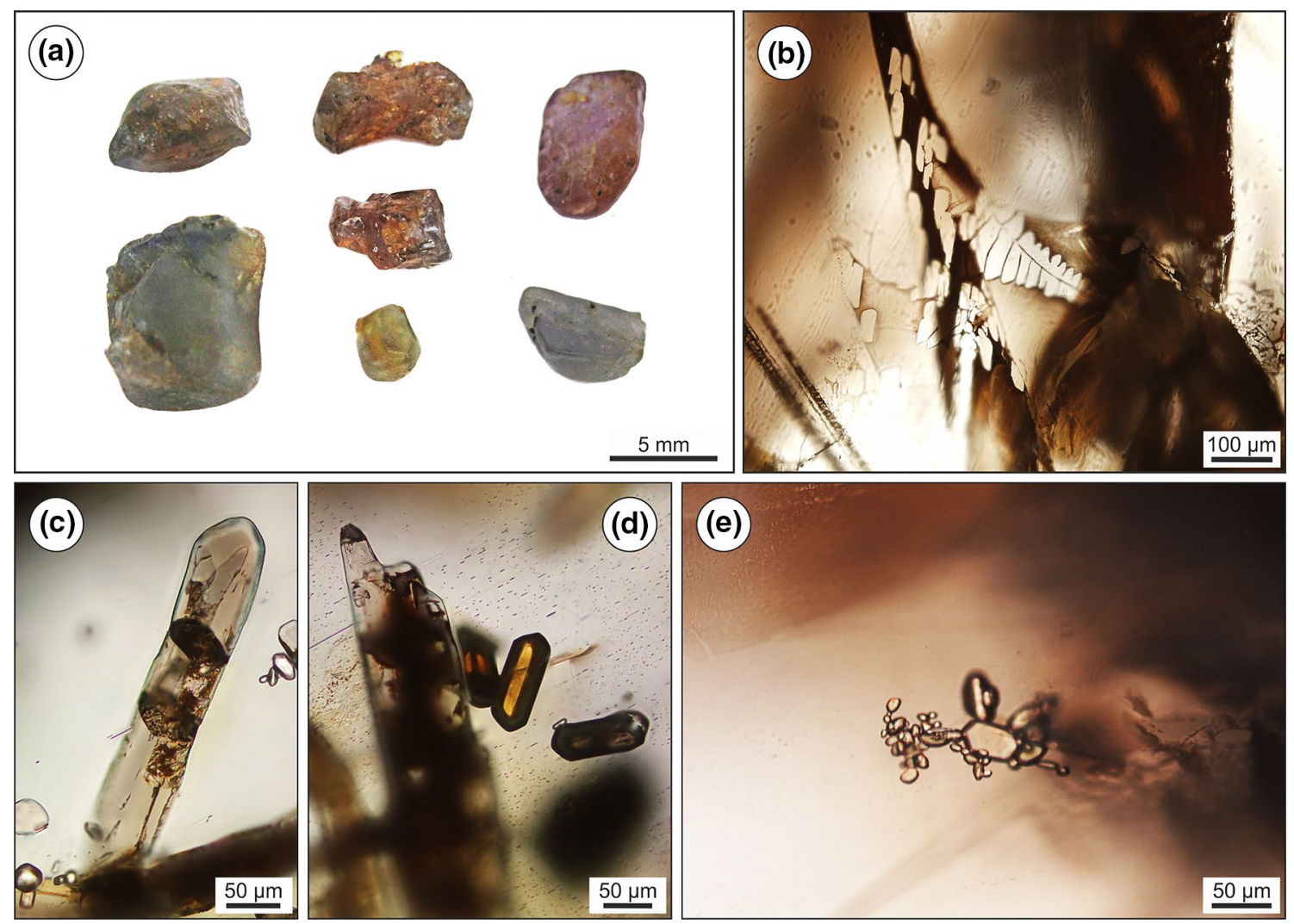

Fig. 2 a Rough gem corundum from the La Honda Creek location showing the colour variety. b-e Transmitted light photomicrographs of inclusions in Mercaderes corundum. b Leaf-shaped, presumably dendritic inclusion of unknown composition. c Elongated allanite-
(Ce) crystal, along with a group of small zircon crystals (near the right margin). d Assemblage of a large allanite-(Ce) crystal (centre) and three honey-coloured to dark brown rutile crystals. e Group of transparent zircon crystals of euhedral to rounded shape

Single-crystal X-ray diffraction analysis was done by means of a Huber 5042 four-circle diffractometer using non-monochromatised Mo radiation from a sealed-tube source, at $50 \mathrm{kV}$ and $30 \mathrm{~mA}$ operation power. Analytical settings of Hejny et al. (2012) were used, and the fitting procedure was done as implemented in the SINGLE software (Angel and Finger 2011). Chemical analyses by SEM-EDS were performed by means of a JEOL JSM 6610-LV system, using the operating software Esprit 2.0. The accelerating voltage was $15 \mathrm{kV}$, and the beam current was $25 \mathrm{pA}$.

\section{Results and discussion}

\section{Identification of solid inclusions}

The Mercaderes corundum is rich in fluid inclusions, which appear under the optical microscope as tubes (presumably formed upon healing of former fissures) or have leaf- or dendrite-like shapes (Fig. 2b). Using Raman and PL spectroscopy (Fig. 3), we found that among the solid inclusions, 
Fig. 3 a Representative Raman spectra of host corundum and zircon inclusion, obtained with 785-nm (shown grey) and 473nm excitation (shown black). Minor emissions of $\mathrm{Dy}^{3+}\left({ }^{4} \mathrm{~F}_{9 / 2}\right.$ $\rightarrow{ }^{6} \mathrm{H}_{15 / 2}$ transition; obtained with 473-nm excitation) and $\mathrm{Nd}^{3+}\left({ }^{4} \mathrm{~F}_{5 / 2} \rightarrow{ }^{4} \mathrm{I}_{9 / 2}\right.$ transition; under 785-nm excitation) in the zircon spectra are marked with asterisks. b Photoluminescence spectra obtained from an allanite-(Ce) inclusion and reference minerals, showing the ${ }^{4} \mathrm{~F}_{3 / 2} \rightarrow$ ${ }^{4} \mathrm{I}_{9 / 2}$ transition of $\mathrm{Nd}^{3+}(785-\mathrm{nm}$ excitation)
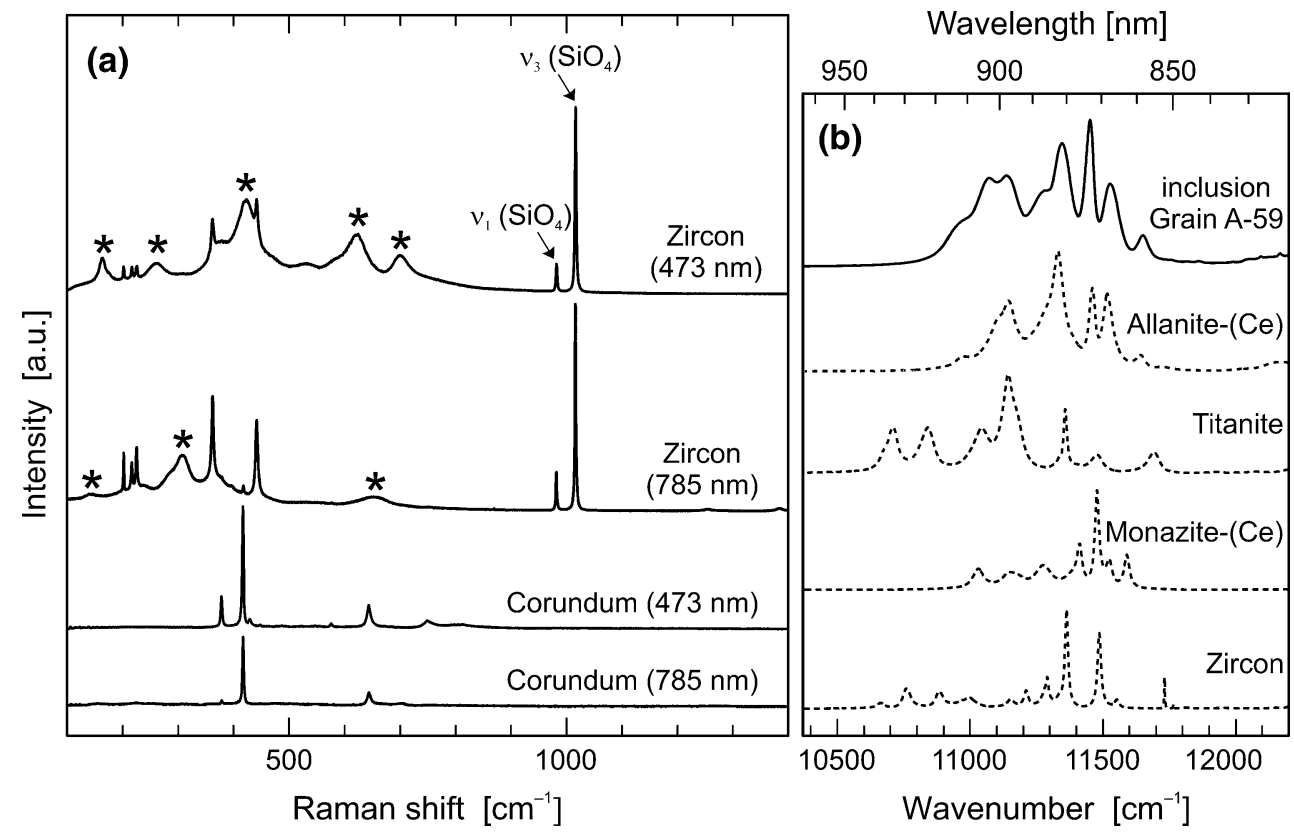

zircon and rutile are the most common mineral species (Fig. 2c-e). Apatite, feldspar, and epidote-group mineral inclusions (Fig. 2c, d) were detected much more rarely. Two different types of zircon inclusions were found. Most zircon inclusions are colourless, euhedral (doubly terminated prismatic) crystals (cf. 2c, e) that occasionally contain tiny inclusions themselves. The second type of zircon inclusions is scarce. These are fairly rounded, have dark, poorly transparent interior regions, and are surrounded by tension halos and fractures in the host corundum (compare photomicrograph in Fig. 5). Sizes of zircon inclusions range between 5 and $90 \mu \mathrm{m}$. Zircon crystals may occur either as single grains or accumulated in clusters of several, randomly oriented crystals (Fig. 2e). Rutile inclusions have prismatic to needle-like shapes; they are either euhedral or rounded. The sizes range from a few micrometres up to ca. $1 \mathrm{~mm}$, and the colour varies between reddish and light yellowish brown (honey coloured; then rutile appears translucent; Fig. 2d) and dark brown to black (then poorly to non-transparent). Apatite inclusions are transparent and predominantly xenomorphic; they are often surrounded by dark halos. Feldspar appears also transparent but occurs always as distinctly rounded grains. It should be noted that solid inclusions in the Mercaderes corundum generally appear "fresh" and do not show any corrosion or other alteration features.

Another type of inclusion, occurring as elongated and transparent crystals with well-visible internal cleavage (Fig. 2c, d), was difficult to identify. The Raman spectra obtained are somehow inconclusive. Spectra are similar to those of allanite-(Ce) (cf. Čopjaková et al. 2015), clinozoisite, and other minerals of the epidote group, but it was impossible to assign them reliably to a certain mineral species. One inclusion was therefore extracted by mechanical preparation and subjected to a single-crystal analysis. The cell parameters were determined at 8.876 (2), 5.644 (2), and 10.114 (2) $\AA$, which again matches roughly to cell constants of epidote-group minerals. Energy-dispersive $\mathrm{X}$-ray analysis in the SEM yielded an approximate chemical composition of $43 \mathrm{wt} \% \mathrm{SiO}_{2}, 29 \mathrm{wt} \% \mathrm{Al}_{2} \mathrm{O}_{3}, 13 \mathrm{wt} \%$ $\mathrm{CaO}, 6$ wt $\% \mathrm{FeO}, 3.5 \mathrm{wt} \% \mathrm{Ce}_{2} \mathrm{O}_{3}, 2.5 \mathrm{wt} \% \mathrm{La}_{2} \mathrm{O}_{3}, 1.4 \mathrm{wt} \%$ $\mathrm{MgO},<1 \mathrm{wt} \% \mathrm{Nd}_{2} \mathrm{O}_{3}$, and $<1 \mathrm{wt} \% \mathrm{Y}_{2} \mathrm{O}_{3}$. We hence assign tentatively the mineral under discussion to a REE-bearing member of the epidote group, but in most cases presumably allanite-(Ce) (for a discussion of chemical compositions of REE-bearing epidote-group minerals see Ercit 2002).

This assignment is supported by our PL spectra (Fig. 3b). Luminescence spectroscopy (Gaft et al. 2005; Richter et al. 2008; Lenz et al. 2013) may be used as fingerprinting tool in mineral identification, which is especially straightforward in the case of the PL emission of REEbearing accessory species (Lenz et al. 2015). The emission of a certain $\mathrm{REE}^{3+}$-related centre in different host minerals is characterised by groups of narrow bands that occur at fairly similar energies but show different fine structures. The latter is due to different splitting into sublevels (Stark levels), depending on crystal-field effects, that is, different local environment of the $\mathrm{REE}^{3+}$ ions depending on their host crystal structure. Consequently, the fine structure observed for a certain REE emission may allow one to determine the host crystal. Here we found that the fine structure of the ${ }^{4} \mathrm{~F}_{3 / 2} \rightarrow{ }^{4} \mathrm{I}_{9 / 2}$ electronic transition of $\mathrm{Nd}^{3+}$ (observed in the range 10,600-11,900 $\mathrm{cm}^{-1}$ ) in the spectra of the Mercaderes inclusions under discussion concurs 
reasonably well with that of allanite-(Ce) (Fig. 3b). The in situ identification of allanite-(Ce) may be possible with relative ease, based on the $\mathrm{Nd}^{3+}$ emission spectrum.

It has been discussed that at present, provenance assignment is still impossible for Colombian corundum (DurocDanner 2003). The PL-based detection of inclusions of allanite-(Ce) could be a practical diagnostic for corundum from Colombia. This is because allanite- $(\mathrm{Ce})$ occurs most rarely in gem corundum. Except from inclusions of this mineral in Colombian corundum (Sutherland et al. 2008), only one allanite- $(\mathrm{Ce})$ inclusion has been discovered in a single Kashmir sapphire specimen (Hänni 1990) thus far. In contrast, the recent Raman-based discovery of inclusions of allanite-(Ce) in alluvial sapphire from Montana (Zwaan et al. 2015) appears doubtful, for the following reasons. First, Raman spectra of epidote-group minerals typically show intense bands related to $\mathrm{Si}_{2} \mathrm{O}_{7}$ vibrations in the spectral range above $700 \mathrm{~cm}^{-1}$ (compare Le Cléach and Gillet 1990), which are not seen in the spectrum of Zwaan et al. (2015). Second, Zwaan et al. (2015) have supported the assignment of their spectrum to allanite-(Ce) by the match with RRUFF "allanite-(Ce)" spectrum R080092 (www.rruff.info). The latter spectrum was obtained from an initially metamict allanite-(Ce) sample from Arendal, Norway, after heat treatment at $1000{ }^{\circ} \mathrm{C}$ for several hours. It is however well known that allanite decomposes into a multiphase assemblage at above $650{ }^{\circ} \mathrm{C}$ (Čobić et al. 2010). This in turn raises serious doubts regarding the mineralogical composition of the sample that was analysed in RRUFF analysis R080092 and hence also the sample of Zwaan et al. (2015). The same problem seems to exist for the "allanite-(Ce)" spectrum of López and Frost (2015), who claimed to have found this mineral in marble from Chillagoe, northern Queensland; however that assignment was based on R080092 (which actually is reminiscent of the Raman spectrum of haematite) as well.

\section{Raman analysis of zircon inclusions}

One hundred zircon inclusions were found in the six corundum specimens investigated. These inclusions were subjected to Raman analyses to determine their structural state. In the Raman analysis of minerals, it is mandatory to check for potential laser-induced PL to avoid possible misinterpretations (see discussion in Nasdala et al. 2012). If the Raman signal is affected significantly by emissions, it is advisable to choose a different excitation wavelength, which causes no or at least less disturbing PL. Also, even if a spectroscopic signal is recognised as luminescence, its correct interpretation may not be straightforward but may require backup by complementary methods. To provide one example, Amizadeh (1997) recognised that a group of intense, narrow bands in the "Raman" spectrum of alumina (632.8-nm excitation) was luminescence. However, this author assigned the observation to iron impurity (whereas it is due to vibronic sidebands of $\mathrm{Cr}^{3+}$; Rothamel et al. 1983).

A similar problem has already occurred in the Raman analysis of Colombian corundum. Sutherland et al. (2008) described two different types of zircon inclusions, based on the observation of two different Raman spectra of zircon. However, the main difference between the two spectra was merely the background: one showed Raman bands atop a flat background, whereas the other was characterised by strong increase of a broadband background phenomenon towards higher Raman shifts. Sutherland et al. (2008) recognised correctly that the broad background in the latter was due to laser-induced PL, but they assigned this phenomenon to REEs, such as Pr. The latter assignment appears most questionable, considering that the emissions of most $\mathrm{REE}^{3+}$ ions in zircon, and in particular that of $\mathrm{Pr}^{3+}$, are characterised by groups of narrow bands (Gaft et al. 2000; Blasse and Grabmaier 1994). Unfortunately, Sutherland et al. (2008) failed to report the laser excitation they had used in their Raman study. We therefore can only speculate that the broad background luminescence underlying the zircon Raman spectrum is due to the broadband $\mathrm{Cr}^{3+}$ emission of the host corundum, as it would be excited by the green emission of an $\mathrm{Ar}^{+}$laser. If this was the case, the background phenomenon reported by Sutherland et al. (2008) the host corundum and hence is not related to the zircon inclusion. Spectroscopic (i.e. Raman and PL) analyses with alternative excitation wavelengths would help to omit such uncertainties.

In the present study, we found blue $(473 \mathrm{~nm})$ and near-infrared $(785 \mathrm{~nm})$ excitation to be most suitable for obtaining Raman spectra of zircon included in corundum, whereas Raman spectra excited with green or red laser excitation were affected, or even fully obscured, by the intense sidebands of $\mathrm{Cr}^{3+}$ in the corundum structure (Rothamel et al., 1983). The blue and the near-infrared laser were both found to excite moderately intense emissions of REEs in zircon; however, their interference with the zircon Raman spectrum is clearly less disturbing, when compared with the $\mathrm{Cr}$ emission. In zircon spectra excited with the 473nm laser, the emission of trace-Dy ${ }^{3+}\left({ }^{4} \mathrm{~F}_{9 / 2} \rightarrow{ }^{6} \mathrm{H}_{15 / 2}\right.$ electronic transition) obscures the Raman signal in the range below $950 \mathrm{~cm}^{-1}$ (Fig. 3a). Spectra obtained under 785-nm excitation are affected by emission lines that occur below $750 \mathrm{~cm}^{-1}$ Raman shift (Fig. 3a); they are presumably due to the ${ }^{4} \mathrm{~F}_{5 / 2} \rightarrow{ }^{4} \mathrm{I}_{9 / 2}$ electronic transition of traces of $\mathrm{Nd}^{3+}$. In both cases the $\mathrm{SiO}_{4}$ stretching Raman bands at around $1000 \mathrm{~cm}^{-1}$ (whose evaluation provides a measure of the degree of radiation damage; Nasdala et al. 1995) were affected neither by emissions of REEs in zircon nor by emissions of the host corundum (see spectra in Fig. 3a). In the present study, Raman spectra of zircon inclusions were 
obtained preferentially with infrared excitation, because of the higher spectral resolution of the dispersive spectrometer at longer wavelengths.

Most zircon inclusions in the Mercaderes corundum were found to be nearly colourless, euhedral, and apparently homogenous. These inclusions yielded an insignificantly to at the most slightly broadened $v_{3}\left(\mathrm{SiO}_{4}\right)$ Raman band (FWHMs $1.8-2.3 \mathrm{~cm}^{-1}$ ), indicating very minor radiation damage. The second type of zircon inclusions (dark, rounded) comprises only a small fraction, in the present study fourteen out of a total of 100 . These inclusions showed internal heterogeneity, with $v_{3}\left(\mathrm{SiO}_{4}\right)$ FWHMs varying between $2.3 \pm 0.3$ and $10.9 \pm 0.5 \mathrm{~cm}^{-1}$, indicating significant heterogeneous radiation damage in these inclusions (cf. Nasdala et al. 1995, 2001; Zhang et al. 2000a).

As no chemical information on the zircon inclusions could be obtained, we may merely speculate that the wellordered state of colourless zircon inclusions, indicating low levels of radioactive self-irradiation, is due to the zircons' low $\mathrm{U}$ and Th contents, their young age(s), or both. This seems to correspond very well with the young formation age of the Mercaderes corundum of ca. $10 \mathrm{Ma}$, determined by Sutherland et al. (2008) from colourless and transparent, columnar, terminated zircon crystals, allanite-(Ce), and fluorapatite inclusions. In contrast, no clear interpretation of the mild to moderate-but nevertheless significantdegrees of radiation damage of the dark zircon inclusions can be given at the present state. Their Raman FWHMs correspond to effective self-irradiation doses of $0.1-0.7$ alpha events per gram (Nasdala et al. 2004) whose accumulation over a 10-myr period would require $\mathrm{U}$ and Th concentrations in the wt\% range, which is well above typical actinide concentration levels in zircon. There is of course the possibility that the dark inclusions consist of zircon and a highly radioactive phase, but no indication of the latter was detected in our Raman study. Another possible explanation is that such zircon inclusions are protogenetic in nature, and the zircon was already radiation damaged at the time of the entrapment and has not experienced complete structural recovery upon corundum formation (as shown for zircon inclusions in kimberlite; Nasdala et al. 2014).

The main result of our study is that a certain fraction of the zircon inclusions does show radiation damage. It is well known that thermal annealing at elevated temperatures above $1200{ }^{\circ} \mathrm{C}$ reconstitutes the structural state of zircon (Zhang et al. 2000b; Wanthanachaisaeng et al. 2006). Gem corundum is commonly subjected to thermal enhancement at $1300-1800{ }^{\circ} \mathrm{C}$ (Nassau 1981; Abraham 1982), depending on the designated result. The treatment can be revealed easily by stress fractures especially around inclusions, and decomposition features at host-inclusion interfaces (cf. Wanthanachaisaeng 2007). Such treatment, even if done only for a few hours, would result in zircon recovery or decomposition (Wanthanachaisaeng et al. 2006). The radiation damage detected in the zircon inclusions studied here hence allows us to exclude that the samples under study have ever been subjected to high-temperature gem enhancement.

More recently, the enhancement of gem corundum at much lower temperatures of $800-1200{ }^{\circ} \mathrm{C}$ has become more popular, for instance applied to remove the blue-colour component from pink sapphire (McClure et al. 2010, and references therein). Unravelling such lower-temperature treatment is more challenging. Clear microscopic indications have not been found thus far, and possible effects on the radiation damage of zircon and other radioactive inclusions may remain minor, especially if the treatment was done for short times only.

\section{Determination of compressive stresses}

Most zircon inclusions are surrounded by a halo of strain birefringence in their host corundum, when observed in cross-polarised transmitted light. This indicates that the zircon crystals are affected by compressive stress. Note that in some cases, stress haloes around zircon inclusions in corundum have been detected even after partial stress release due to sample preparation and exposure of zircon inclusions to the polished sample surface (cf. cathodoluminescence haloes reported by Elmaleh et al. 2015).

The compressive stress acting on a zircon inclusion can be estimated in situ, based on the pressure-induced upshift of zircon Raman bands (Knittle and Williams 1993; Nasdala et al. 2008; Schmidt et al. 2013). In doing so, it has to be considered cautiously that the positions of Raman bands of minerals may shift also due to significant chemical variations in the sample's chemical composition, which may then bias pressure estimates. In the case of zircon, such effects are very minor, because both igneous and metamorphic zircon incorporate only trace amounts of non-formula elements upon primary growth. The only exception is hafnium (zircon typically contains $0.6-2.0 \mathrm{wt} \% \mathrm{HfO}_{2}$ ). Major effects of Hf on Raman shift values can be excluded: a Raman study of the zircon-hafnon solid solution (Hoskin and Rodgers 1996) indicated that the $v_{3}\left(\mathrm{SiO}_{4}\right)$ Raman band of Hf-rich natural zircon is upshifted by less than $0.3 \mathrm{~cm}^{-1}$, compared to Hf-poor zircon. Elevated U concentrations on the order of several thousand ppm would in contrast cause downshifts of the $v_{3}\left(\mathrm{SiO}_{4}\right)$ band by a few tenths of $\mathrm{cm}^{-1}$ (Geisler et al. 2003; Nasdala et al. 2004). Overall, effects of the chemical composition of zircon on Raman band positions of this mineral are mostly insignificant.

In DAC (diamond anvil cell) studies, Nasdala et al. (2008) and Schmidt et al. (2013) have analysed the effect of hydrostatic compression of zircon on the Raman spectrum of this mineral. Nasdala et al. (2008) investigated 
zircon samples representing the range from crystalline to severely radiation damaged. These authors found that compressive stress results in notable upshift of the $v_{3}\left(\mathrm{SiO}_{4}\right)$ Raman band (average shift $5.7 \pm 0.3 \mathrm{~cm}^{-1}$ per GPa) but does not cause significant changes of the FWHM of this band. Later, Schmidt et al. (2013) reported similar results for synthetic zircon, namely $v_{3}\left(\mathrm{SiO}_{4}\right)$ upshifts of 5.69 and $5.77 \mathrm{~cm}^{-1} / \mathrm{GPa}$ at constant FWHM. Also, the radiation damage-induced downshift of the $v_{3}\left(\mathrm{SiO}_{4}\right)$ Raman band accompanied by a clear FWHM increase of this band is well known (Nasdala et al. 2001). These results imply that the spectral position of the $v_{3}\left(\mathrm{SiO}_{4}\right)$ Raman band may be complexly affected by radiation damage and stress. However, effects of the two causes can be resolved, based on the consideration that (homogeneous) stress/strain does not affect FWHMs. Consequently, band broadening must be due mainly to radiation damage.

The above findings allow us to estimate a hypothetical "zero-pressure Raman band position" for the detected radiation damage. The difference of this hypothetical and the actually observed band position may then be used for stress estimations. Note that our approach is different from that of Wang et al. (2006) who used $v_{3}\left(\mathrm{SiO}_{4}\right)$ values of $1007.8-1008.4 \mathrm{~cm}^{-1}$, obtained from two free-standing zircon crystals, as "zero-pressure Raman shift", even though their zircon inclusions showed notable band broadening. Neglecting the band downshift induced by radiation damage results in calculation of too low band upshift and hence underestimated compressive stress in the study of Wang et al. (2006).

Raman data obtained for a wide range of (unstressed) zircon samples indicate a nearly linear decrease of the band position with increasing FWHM, for mildly to moderately radiation-damaged zircon with FWHM $\left[v_{3}\left(\mathrm{SiO}_{4}\right)\right]$ $\leq 15 \mathrm{~cm}^{-1}$. Based on the data of Nasdala et al. $(2001,2004$, 2008), we have calculated the simple linear regression

$\tilde{\boldsymbol{v}}$ (zero) $\left[\mathrm{cm}^{-1}\right]=1009.5-0.7 \times$ FWHM

which we suggest to be used for the calculation of a "zeropressure Raman shift" from the FWHM of the $v_{3}\left(\mathrm{SiO}_{4}\right)$ zircon band of a given zircon inclusion. Based on the average pressure-induced band upshift of ca. $5.7 \mathrm{~cm}^{-1}$ / GPa observed by Nasdala et al. (2008) and Schmidt et al. (2013), we propose to calculate compressive stress $(p)$ of the zircon inclusion by the difference between calculated "zero-pressure Raman shift" and observed Raman shift according to

$p[\mathrm{GPa}]=\frac{\tilde{\boldsymbol{v}}(\text { measured })-\tilde{\boldsymbol{v}}(\text { zero })}{5.7}$

Results for the 100 zircon inclusions in six corundum specimens investigated in the present study are presented in Fig. 4a, b. The calculated band upshifts lie mostly in the range $4-6 \mathrm{~cm}^{-1}$ (min. $3.8 \mathrm{~cm}^{-1}$; $\max .12 .4 \mathrm{~cm}^{-1}$ ) which, according to Eq. 2, indicates compressive stresses of about 0.8-1.2 GPa (min. $0.7 \pm 0.2 \mathrm{GPa}$; max. $2.2 \pm 0.2 \mathrm{GPa}$ ).

The extensive scatter of calculated stresses among and even within individual zircon inclusions may have several reasons. In some spectra, asymmetric Raman bands were obtained, which biases appreciably the accuracy of fit results. Band asymmetry could be due to (1) heterogeneous band broadening due to partially non-hydrostatic stress (Sharma et al. 1985) or (2) inhomogeneous radiation damage within the sample volume probed (Nasdala et al. 2001).
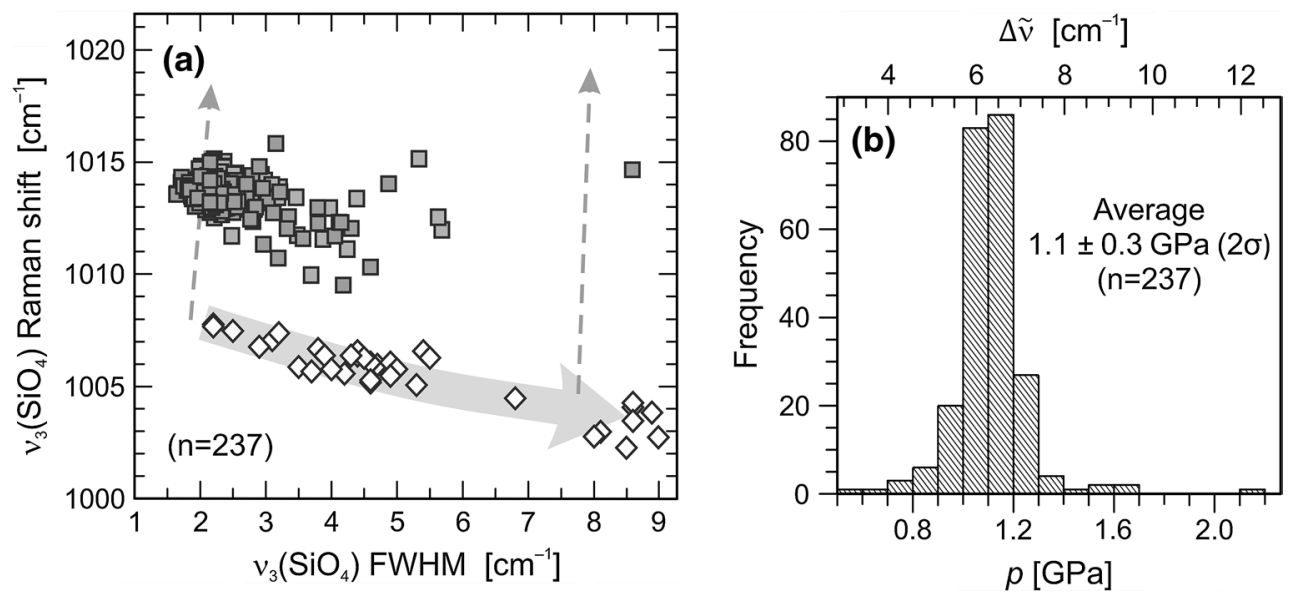

Fig. 4 a Plots of Raman parameters obtained from zircon inclusions (dark grey squares) in six corundum crystals (grains $A-F$ ). Data are shown in comparison with data pairs for Sri Lankan gem zircon (white squares; data from Nasdala et al. 2001); the general trend of spectral changes with increasing radiation damage is visualised by a large grey arrow. The two dashed arrows visualise spectral changes

of two samples with increasing pressure (left, synthetic zircon; right, moderately radiation-damaged zircon M144; data from Nasdala et al. 2008). b Distribution of compressive stress $(p)$ from zircon inclusions inside Mercaderes corundum $(\Delta \tilde{v}$ is the difference between calculated "zero-pressure Raman shift" and observed Raman shift) 
Also, zircon inclusions surrounded by radial fractures (cf. photomicrograph in Fig. 5) are likely to have experienced partial and inhomogeneous stress release.

The spectral position of the $R_{1}$ emission line of $\mathrm{Cr}^{3+}$ (Nelson and Sturge 1965) in corundum adjacent to zircon inclusions was observed in the range 14,402.0$14,399.5 \mathrm{~cm}^{-1}$ (which corresponds to $694.35-694.47 \mathrm{~nm}$ wavelength). Based on the calibration of Mao et al. (1986) for the pressure-induced $R_{1}$ upshift, the above values correspond to compressive stresses in the range $0.2-0.5 \mathrm{GPa}$ only.

It is worthy of note that compressive stresses determined for the host corundum adjacent to zircon inclusions are about three times lower than stresses of zircon inclusions themselves. This vast difference can be explained considering the stress distribution in a host-inclusion system. It has been known for a long time (Goodier 1933; Eshelby 1957) that when a spherical inclusion is under a residual pressure, the stress in the host close to the inclusion is not isotropic.
Rather, a radial stress and two tangential stresses are developed, even if both inclusion mineral and host mineral are elastically isotropic (Zhang 1998; Angel et al. 2015). As a consequence, the pressure (equal to the average of the three normal stresses) in the host can never match the pressure in the inclusion. From force balance we must expect that at the interface between the two minerals, only the radial component of the stress in the host matches the stress in the inclusion. The validity of these results has been extended only recently to real systems with non-spherically shaped inclusion (i.e. comparable to the inclusions investigated in the present study) by Mazzucchelli et al. (2016).

The stress calibrations (PL for corundum and Raman for zircon) were performed under hydrostatic stress, a condition that however does not apply to the host in close proximity to an inclusion. Therefore, any hydrostatic calibration does not allow one to determine solely the radial component of the stress, but rather it must yield a result that is affected by all components of the anisotropic stress field
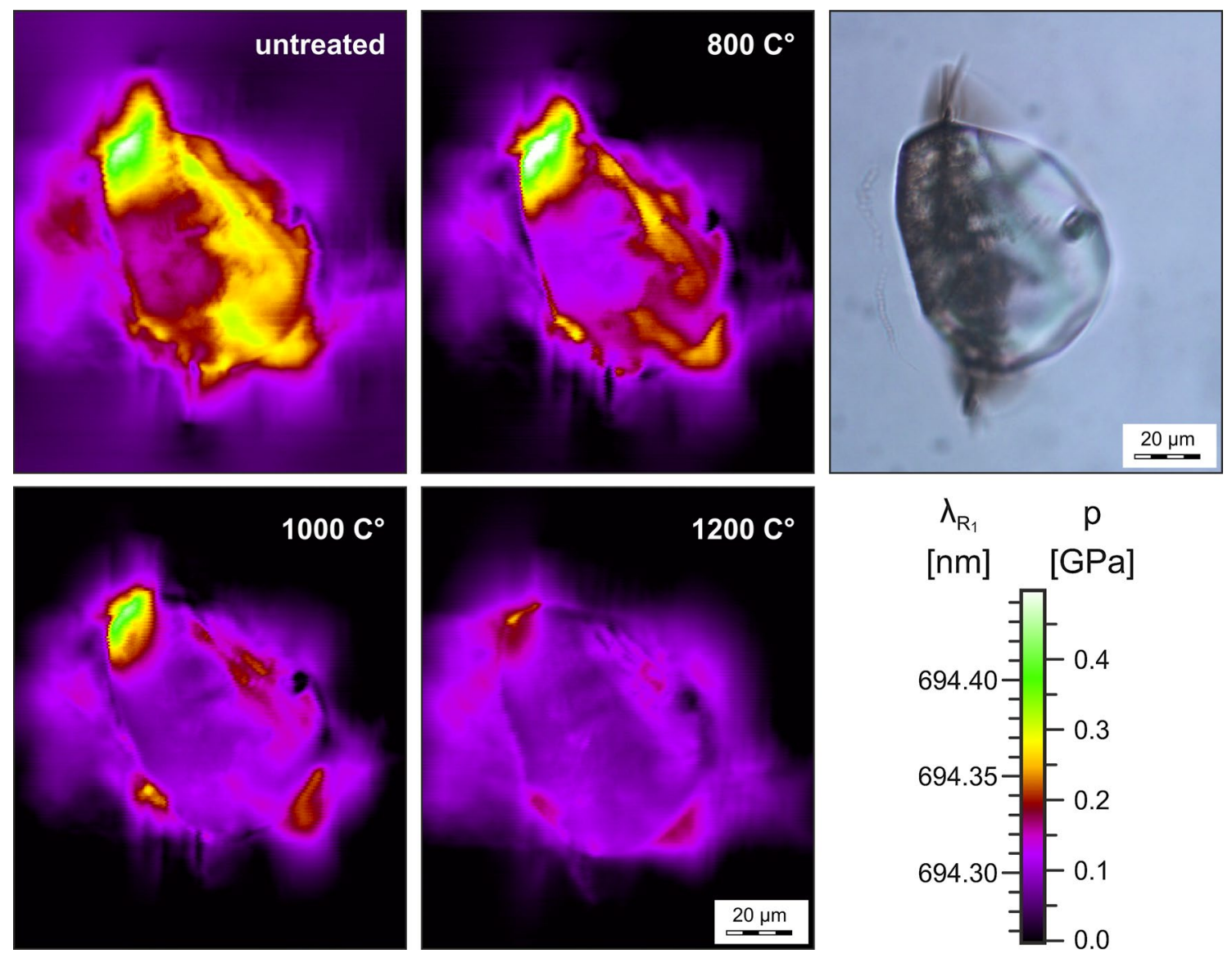

Fig. 5 Colour-coded hyperspectral maps of the spectral position of the $\mathrm{Cr}^{3+} R_{1}$ emission line, obtained from corundum $\mathrm{B}$ around a zircon inclusion (473-nm excitation). Mapping was done with the initial sample, as well as after three steps of heat treatment for $24 \mathrm{~h}$ each. The mapped area corresponds to the transmitted light photomicrograph (upper right image). As the $R_{1}$ line shifts with increasing com- pression (Mao et al. 1986), the photoluminescence maps visualise the distribution of compressive stress in the host corundum around the zircon inclusion. Pressures up to $0.5 \mathrm{GPa}$ were observed in the untreated sample, whilst much lower stress was detected after gradual annealing 
acting on that point. This consideration explains that, and why, different stress values were detected in the host and the inclusion, respectively.

Moreover, the stress determination in the host corundum is likely affected by the limited depth resolution of the PLmapping technique. Note that in the upper two PL maps in Fig. 5 ("untreated" and "800 ${ }^{\circ} \mathrm{C}$ "), analysis locations that yielded $0.5 \mathrm{GPa}$ (white colour coding) and $0.1 \mathrm{GPa}$ (purple colour coding) are less than $10 \mu \mathrm{m}$ apart, indicating extreme lateral strain gradients in the host corundum adjacent to the zircon inclusion. Similar strain gradients in the corundum are to be considered in the vertical direction, i.e. along the laser-beam orientation. The depth resolution performance of a confocal spectrometer is much worse than the lateral resolution. Even though the spectrometer was operated in the confocal mode, it is therefore clear that the sample volume analysed must have comprised a range of compressive strains, with the analysis result not yielding the maximum but representing some kind of average stress. This bias is to be considered here even more as the depth resolution which deteriorates appreciably with increasing distance behind the sample surface of the focal plane inside a solid host (see Fig. 5.4 in Nasdala et al. 2012 and accompanying discussion). Both theoretical and experimental considerations hence imply that the residual pressure on the inclusion, and not that in the host around the inclusion, should be used to estimate the potential $P-T$ path for the host corundum.

The average stress values of $\sim 1.1 \mathrm{GPa}$ determined in the present study anyhow do not provide independent evidence for either magmatic or metamorphic formation (Romero and Rodríguez-Vargas 2002; Duroc-Danner 2002), especially not when the large scatter and potential uncertainty of the stresses calculated are considered.

\section{Temperature treatment}

Based on the observation of significant broadening of Raman bands for a fraction of zircon inclusions, we conclude that these inclusions accumulated significant radiation damage. The same is concluded from haloes of compressive stress in the host corundum surrounding such inclusions. The stress is seen from strain birefringence and upshifted $\mathrm{Cr}$ emission lines (cf. Wanthanachaisaeng et al. 2006), and we assign it to partially hindered volume expansion of the radiation-damaged zircon. The presence of radiation damage in the zircon is interpreted to exclude hightemperature treatment of the host corundum. We attempted to support our interpretation by showing that heat treatment will actually release stress haloes. One of the corundum samples was heat-treated at 800,1000 , and $1200{ }^{\circ} \mathrm{C}$, to anneal gradually the radiation damage in zircon.

That corundum sample (\#B) was studied after each annealing step by PL spectroscopy. Compressive stress in the host corundum in close proximity to a zircon inclusion was estimated from the observed upshift of the $R_{1}$ emission line of $\mathrm{Cr}^{3+}$ (cf. Mao et al. 1986; see also Wanthanachaisaeng et al. 2006; Noguchi et al. 2013). Stress haloes were visualised by hyperspectral PL images produced from point-by-point maps, which show colour-coded distribution of the spectral position of the $R_{1}$ emission line (Fig. 5). We found that the gradual structural recovery of the zircon inclusion is accompanied by a gradual decrease of lateral extension and intensity of the stress halo surrounding the inclusion (Fig. 5). Heating at $800{ }^{\circ} \mathrm{C}$ had only minor effects, whereas the majority of the stress decreased after heating at $1200{ }^{\circ} \mathrm{C}$. These observations concur well with the initial $\left(800{ }^{\circ} \mathrm{C}\right)$ and almost complete $\left(1200{ }^{\circ} \mathrm{C}\right)$ annealing of radiation damage in mildly radiation-damaged zircon (Zhang et al. 2000b).

The compressive stress around the zircon inclusion decreases appreciably but remains heterogeneous after annealing (Fig. 5). This may for instance be due to differences of the thermal expansion coefficients and elastic constants between corundum and zircon, which depend on the relative crystallographic orientation of the inclusion and the host (Noguchi et al. 2013). Also, corpuscular radiation emanating from the zircon may have caused structural damage in the neighbouring corundum (cf. Schuster et al. 2010). Analogous radiation damage in diamond contained in zircon has been described by Smith et al. (2011) and Shimizu and Ogasawara (2014). It may be speculated that at elevated temperature, heterogeneous structural recovery of the radiation-damaged host-inclusion couple causes heterogeneous stress release.

The radiation-damaged zircon inclusion (see Fig. 5) was studied by Raman spectroscopy after the annealings. Structural reconstitution is verified by significant FWHMs decrease (Fig. 6). Annealing at 800 and $1000{ }^{\circ} \mathrm{C}$ caused a downshift of the $v_{3}\left(\mathrm{SiO}_{4}\right)$ band of $0.4-0.8 \mathrm{~cm}^{-1}$, which is consistent with the structural recovery in the sample (Zhang et al. 2000b). Annealing at $1200{ }^{\circ} \mathrm{C}$, in contrast,

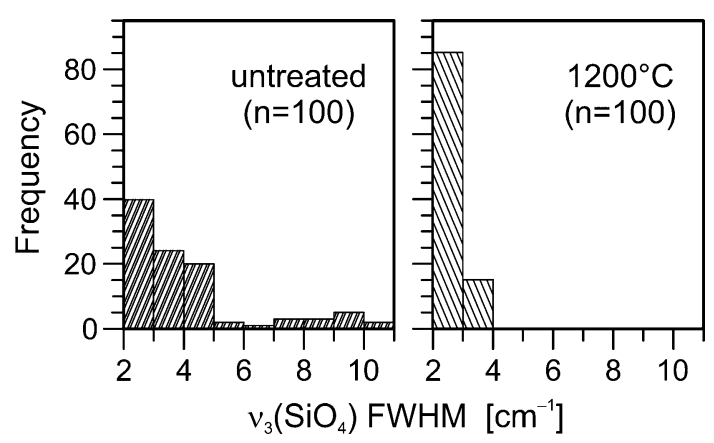

Fig. 6 Plot of FWHM of the $v_{3}\left(\mathrm{SiO}_{4}\right)$ Raman band as obtained from zircon inclusions in corundum $\mathrm{B}$, before (left) and after heat treatment at $1200{ }^{\circ} \mathrm{C}$ for $24 \mathrm{~h}$ (right) 
resulted in an upshift of the $v_{3}\left(\mathrm{SiO}_{4}\right)$ band of $0.5-3.6 \mathrm{~cm}^{-1}$. This phenomenon has already been noticed by Wanthanachaisaeng et al. (2006). These authors suggested that the initial onset of zircon decomposition into oxides at high temperatures possibly may result in the build-up of compressive stress in the remaining zircon, which results in band upshift. This interpretation was strengthened by the results of Váczi et al. (2009) who found that $\mathrm{Al}_{2} \mathrm{O}_{3}$ may have strong influence on the annealing behaviour of partially radiation-damaged zircon: dry annealing causes structural recovery of zircon, whereas decomposition into baddeleyite and amorphous silica is observed only in close proximity to alumina crucible material. A similar decomposition reaction occurs at the interface of zircon inclusion and host corundum (Wanthanachaisaeng et al. 2006), which in turn might not only hinder complete stress relaxation but contribute to the build-up of additional compressive stress. The decomposition, if it occurred at all, was merely initial, as we have mainly detected zircon in our Raman study. A fully conclusive interpretation of the band upshifts of hightemperature annealed zircon inclusions cannot be given at the present state and requires further studies.

\section{Conclusions}

Raman and PL spectroscopy were proven again to be excellent means for the investigation of mineral inclusions, as both techniques provide the opportunity of fast in situ phase identification. In some cases, especially if the Raman signal of an inclusion cannot be obtained or is ambiguous, the identification of a certain inclusion species may be possible based on spectral characteristics of the PL emission. Changes of Raman spectral parameters provide information on the degree of radiation damage accumulated and on stress acting on the inclusion.

Band broadening of zircon inclusions is a reliable indicator of structural radiation damage that must have been accumulated at fairly low temperatures. The observation of notable band broadening of zircon inclusions therefore allows one to exclude high-temperature gem enhancement. The determination of the pressure, at which the host had formed and the inclusion was entrapped, based on the observed compressive stress acting on the inclusion, is likely to be biased in the case of zircon inclusions. The bias is mainly due to the possibility of significant additional compression because of volume increase caused by the accumulation of self-irradiation damage. Further uncertainties arise from (1) inhomogeneous band broadening due to heterogeneity of the chemical composition and/or the distribution of irradiation damage, (2) partial release of compressive stress of the zircon inclusion due to fracturing of the surrounding host, and (3) the possibility of stress being non-hydrostatic.
Apparent mismatches of compressive stresses determined for zircon inclusions and their adjacent host corundum are striking and deserve further investigation. In the present study, compressive stresses determined for zircon inclusions average $1.1 \mathrm{GPa}$, which is significantly higher compared to compressive stresses averaging $0.4 \mathrm{GPa}$ calculated from the upshift of the $\mathrm{Cr}^{3+} R_{1}$ emission line of the respective host corundum.

Stress values on the order of $1.1 \mathrm{GPa}$ would support a metamorphic formation model of Colombian corundum although this cannot be regarded as independent evidence. However, associated kyanite crystals with similar inclusion characteristics strengthen the assumption of a metamorphic origin.

Acknowledgments Open access funding provided by University of Vienna. The allanite-(Ce) reference sample from Luzenac was kindly provided by Radek Škoda. Sample preparation was done by Andreas Wagner. We are indebted to Katharina Scheidl and Dan Topa for experimental help and to Wolfgang Zirbs for technical assistance. Matteo Alvaro, Thomas Cramer, Mattia L. Mazzucchelli, Tamás Váczi, and Bhuwadol Wanthanachaisaeng are thanked for helpful discussions. We are indebted to an anonymous expert and Rentaro Shimizu whose constructive comments helped to improve the manuscript. Financial support by the Faculty of Geosciences, Geography and Astronomy, University of Vienna, is gratefully acknowledged.

Open Access This article is distributed under the terms of the Creative Commons Attribution 4.0 International License (http://creativecommons.org/licenses/by/4.0/), which permits unrestricted use, distribution, and reproduction in any medium, provided you give appropriate credit to the original author(s) and the source, provide a link to the Creative Commons license, and indicate if changes were made.

\section{References}

Abraham JSD (1982) Heat treating corundum: the Bangkok operation. Gems Gemol 18(2):79-82

Amizadeh A (1997) Excitation frequency dependence and fluorescence in the Raman spectra of $\mathrm{Al}_{2} \mathrm{O}_{3}$. Appl Spectrosc 51:817-819

Angel RJ, Finger LW (2011) Single: a program to control single-crystal diffractometers. J Appl Crystallogr 44:247-251

Angel RJ, Nimis P, Mazzucchelli ML, Alvaro M, Nestola F (2015) How large are departures from lithostatic pressure? Constraints from host-inclusion elasticity. J Metamorph Geol 33:801-813

Bersani D, Lottici PP (2010) Applications of Raman spectroscopy to gemology. Anal Bioanal Chem 397:2631-2646

Blasse G, Grabmaier B (1994) Luminescence materials. Springer, Berlin, p 248

Burke EAJ (2001) Raman microspectrometry of fluid inclusions. Lithos 139:139-158

Čobić A, Bermanec V, Tomašić N, Škoda R (2010) The hydrothermal recrystallization of metamict allanite-(Ce). Can Mineral 48:513-521

Čopjaková R, Škoda R, Galiová MV, Novák M, Cempírek J (2015) Sc- and REE-rich tourmaline replaced by Sc-rich REE-bearing epidote-group mineral from the mixed (NYF + LCT) Kracovice pegmatite (Moldanubian Zone, Czech Republic). Am Mineral 100:1434-1451 
Dawson P, Hargreave MM, Wilkinson GF (1971) The vibrational spectrum of zircon $\left(\mathrm{ZrSiO}_{4}\right)$. J Phys C Solid State 4:240-256

Devanathan R, Corrales LR, Weber WJ, Chartier A, Meis C (2006) Molecular dynamics simulation of energetic uranium recoil damage in zircon. Mol Simulat 32:1069-1077

Dubessy J, Poty B, Ramboz C (1989) Advances in C-O-H-N-S fluid geochemistry based on micro-Raman spectrometric analysis of fluid inclusions. Eur J Mineral 1:517-534

Duroc-Danner JM (2002) A study of Colombian corundum. Dissertation, University of Nantes

Duroc-Danner JM (2003) Gem-quality corundum from Colombia: localities and inclusions. Gems Gemol 39:329-331

Elmaleh E, Karampelas S, Schmidt ST, Galster F (2015) Zircon inclusions in blue sapphire. In: Proceedings of the 34th international gemological conference, Vilnius, Lithuania, August, 2015, pp 51-52. http://www.igc-gemmology.net/igc34-proceedings/content/pdf/IGC3425.pdf

Ercit TS (2002) The mess that is "allanite". Can Mineral 40:1411-1419

Eshelby JD (1957) The determination of the elastic field of an ellipsoidal inclusion, and related problems. Proc R Soc A 241:376-396

Ewing RC (1994) The metamict state:1993-the centennial. Nucl Instrum Methods B 91:22-29

Ewing RC, Chakoumakos BC, Lumpkin GR, Murakami T (1987) The metamict state. MRS Bull 12:58-66

Fritsch E, Rondeau B, Hainschwang T, Karampelas S (2012) Raman spectroscopy applied to gemmology. In: Dubessy J, Caumon M-C, Rull F (eds) Applications of Raman spectroscopy to earth sciences and cultural heritage, vol 12., EMU notes in mineralogyEuropean Mineralogical Union and Mineralogical Society of Great Britain and Ireland, Ireland, pp 455-489

Gaft M, Panczer G, Reisfeld R, Shinno I (2000) Laser-induced luminescence of rare-earth elements in natural zircon. J Alloy Compd 300:267-274

Gaft M, Reisfeld R, Panczer G (2005) Modern luminescence spectroscopy of minerals and materials. Springer, Berlin, p 356

Geisler T, Burakov BE, Zirlin V, Nikolaeva L, Pöml P (2003) A Raman spectroscopic study of high-uranium zircon from the Chernobyl "lava". Eur J Mineral 17:883-894

Gillet P, Sautter V, Harris J, Reynard B, Harte B, Kunz M (2002) Raman spectroscopic study of garnet inclusions in diamonds from the mantle transition zone. Am Mineral 87:312-317

Goodier JN (1933) Concentration of stress around spherical and cylindrical inclusions and flaws. J Appl Mech 55:39-44

Hänni HA (1990) A contribution to the distinguishing characteristics of sapphire from Kashmir. J Gemmol 22:67-75

Hejny C, Miletich R, Jasser A, Schouwink P, Crichton W, Kahlenberg V (2012) Second order P c2-P31c structural transition and structural crystallography of the cyclosilicate benitoite, $\mathrm{BaTiSi3O}$, at high pressure. Am Mineral 97:1749-1763

Holland HD, Gottfried D (1955) The effect of nuclear radiation on the structure of zircon. Acta Cryst 8:291-300

Hoskin PWO, Rodgers KA (1996) Raman spectral shift in the isomorphous series $\left(\mathrm{Zr}_{1-x} \mathrm{Hf}_{x}\right) \mathrm{SiO}_{4}$. Eur J Solid State Inorg Chem 33:1111-1121

Kiefert L, Hänni HA, Ostertag T (2001) Raman spectroscopic applications to gemmology. In: Lewis IR, Edwards HGM (eds) Handbook of Raman spectroscopy: from the research laboratory to the process line. Marcel Dekker, New York, pp 469-490

Knittle E, Williams Q (1993) High-pressure Raman spectroscopy of $\mathrm{ZrSiO}_{4}$ : observation of the zircon to scheelite transition at $300 \mathrm{~K}$. Am Mineral 78:245-252

Kouketsu Y, Nishiyama T, Ikeda T, Enami M (2014) Evaluation of residual pressure in an inclusion-host system using negative frequency shift of quartz Raman spectra. Am Mineral 99:433-442
Le Cléaćh L, Gillet P (1990) IR and Raman spectroscopic study of natural lawsonite. Eur J Mineral 2:43-53

Lee JKW, Tromp J (1995) Self-induced fracture generation in zircon. J Geophys Res Sol Earth 100:17753-17770

Lenz C, Nasdala L (2015) A photoluminescence study of $\mathrm{REE}^{3+}$ emissions in radiation-damaged zircon. Am Mineral 100:1123-1133

Lenz C, Talla D, Ruschel K, Skoda R, Götze J, Nasdala L (2013) Factors affecting the $\mathrm{Nd} 3+(\mathrm{REE} 3+)$ luminescence of minerals. Mineral Petrol 107:415-428

Lenz C, Nasdala L, Talla D, Hauzenberger C, Seitz R, Kolitsch U (2015) Laser-induced $\mathrm{REE}^{3+}$ photoluminescence of selected accessory minerals - an "advantageous artefact" in Raman spectroscopy. Chem Geol 415:1-16

Lin JF, Degtyareva O, Prewitt CT, Dera P, Sata N, Gregoryanz E, MAO HK, Hemley RJ (2004) Crystal structure of a high-pressure/high-temperature phase of alumina by in situ X-ray diffraction. Nat Mater 3:389-393

Liu LG, Mernagh TP, Jaques AL (1990) A mineralogical Raman spectroscopy study on eclogitic garnet inclusions in diamonds from Argyle. Contrib Mineral Petrol 105:156-161

López A, Frost RL (2015) Identification of allanite $(\mathrm{Ce}, \mathrm{Ca}, \mathrm{Y})_{2}(\mathrm{Al}$, $\left.\mathrm{Fe}^{3+}\right)_{3}\left(\mathrm{SiO}_{4}\right)_{3} \mathrm{OH}$ found in marble from Chillagoe, Queensland using Raman spectroscopy. Spectrochim Acta A 138:229-233

Mao HK, Xu J, Bell PM (1986) Calibration of the ruby pressure gauge to 800 kbar under quasi-hydrostatic conditions. J Geophys Res 91:4673-4676

Mazzucchelli ML, Burnley P, Angel RJ, Domeneghetti MC, Nestola F, Alvaro M (2016) Elastic geobarometry: uncertainties arising from the shape of the inclusion. In: 12nd European mineralogical conference, Rimini, Italy, September, 2016. Book of Abstracts, p 232

McClure SF, Kane RE, Sturman N (2010) Gemstone enhancement and its detection in the $2000 \mathrm{~s}$. Gems Gemol 46:218-240

Meldrum A, Zinkle SJ, Boatner LA, Ewing RC (1999) Amorphization, recrystallization, and phase decomposition in the $\mathrm{ABO}_{4}$ orthosilicates. Phys Rev B 59:3981-3992

Murakami T, Chakoumakos BC, Ewing RC, Lumpkin GR, Weber WJ (1991) Alpha-decay event damage in zircon. Am Mineral $76: 1510-1532$

Nasdala L, Irmer G, Wolf D (1995) The degree of metamictization in zircons: a Raman spectroscopic study. Eur J Mineral 7:471-478

Nasdala L, Wenzel M, Vavra G, Irmer G, Wenzel T, Kober B (2001) Metamictisation of natural zircon: accumulation versus thermal annealing of radioactivity-induced damage. Contrib Mineral Petrol 1412:125-144

Nasdala L, Reiners PW, Garver JI, Kennedy AK, Stern RA, Balan E (2004) Incomplete retention of radiation damage in zircon from Sri Lanka. Am Mineral 89:219-231

Nasdala L, Miletich R, Ruschel K, Váczi T (2008) Raman study of radiation-damaged zircon under hydrostatic compression. Phys Chem Mineral 35:597-602

Nasdala L, Hanchar JM, Rhede D, Kennedy AK, Váczi T (2010) Retention of uranium in complexly altered zircon: an example from Bancroft, Ontario. Chem Geol 269:290-300

Nasdala L, Beyssac O, Schopf JW, Bleisteiner B (2012) Application of Raman-based images in the earth sciences. In: Zoubir A (ed) Raman imaging-techniques and applications, vol 5, 168th edn. Springer series in optical sciences. Springer, Berlin, pp 145-187

Nasdala L, Kostrovitsky S, Kennedy AK, Zeug M, Esenkulova SA (2014) Retention of radiation damage in zircon xenocrysts from kimberlites, Northern Yakutia. Lithos 206-207:252-261

Nassau K (1981) Heat treating ruby and sapphire: technical aspects. Gems Gemol 17:121-131

Nelson DF, Sturge MD (1965) Relation between absorption and emission in the region of the $\mathrm{R}$ lines of ruby. Phys Rev 137:A1117-A1130 
Noguchi N, Abduriyim A, Shimizu I, Kamegata N, Odake S, Kagi H (2013) Imaging of internal stress around a mineral inclusion in a sapphire crystal: application of micro-Raman and photoluminescence spectroscopy. J Raman Spectrose 44:147-154

Parkinson CD, Katayama I (1999) Present-day ultrahigh-pressure conditions of coesite inclusions in zircon and garnet: evidence from laser Raman microspectroscopy. Geology 27:979-982

Pearson DG, Brenker FE, Nestola F, McNeill J, Nasdala L, Hutchison MT, Matveev S, Mather K, Silversmit G, Schmitz S, Vekemans B, Vincze L (2014) Hydrous mantle transition zone indicated by ringwoodite included within diamond. Nature 507:221-224

Peucat JJ, Ruffault P, Fritsch E, Bouhnik-Le Coz M, Simonet C, Lasnier B (2007) $\mathrm{Ga} / \mathrm{Mg}$ ratio as a new geochemical tool to differentiate magmatic from metamorphic blue sapphires. Lithos 98:261-274

Pinet M, Smith DC, Lasnier B (1992) Utilité de la microsonde Raman pour l'identification non-destructive des gemmes (compilation d'une sélection représentative de leurs spectres Raman). In: Schubnel H-J, Smith DC (eds) La microsonde Raman en gemmologie, vol II. Association Française de Gemmologie, Paris, pp $11-61$

Rankin AH (2005) Fluid inclusions-tools for geological investigations. In: Selley RC, Cocks R, Plimer I (eds) Encyclopedia of geology, chap 9. Elsevier, Oxford, pp 253-260

Richter D, Gorgen P, Götte T (2008) Monazite cathodoluminescence-a new tool for heavy mineral analysis of siliciclastic sedimentary rocks. Sediment Geol 209:36-41

Romero FH, Rodríguez-Vargas AI (2002) Caracterización mineralógica de los corindones de Mercaderes, Cauca (Colombia). Geol Colomb 27:121-142

Rosasco GJ, Roedder E, Simmons JH (1975) Laser activated Raman spectroscopy for non-destructive partial analysis of individual phases in fluid inclusions in minerals. Science 190:557-560

Rothamel U, Heber J, Grill W (1983) Vibronic sidebands in ruby. J Phys Condens Matter 50:297-304

Schmidt C, Steele-MacInnis M, Watenphul A, Wilke M (2013) Calibration of zircon as a Raman spectroscopic pressure sensor to high temperatures and application to water-silicate melt systems. Am Mineral 98:643-650

Schuster B, Weikusat C, Miletich R, Trautmann C, Neumann R, Fujara $F$ (2010) Influence of radiation damage on ruby as a pressure gauge. Phys Rev B 82(18): 184110

Sharma SK, Mao HK, Bell PM, Xu JA (1985) Measurement of stress in diamond anvils with micro-Raman spectroscopy. J Raman Spectrose 16:350-352

Shimizu R, Ogasawara Y (2014) Radiation damage to Kokchetav UHPM diamonds in zircon: variations in Raman, photoluminescence, and cathodoluminescence spectra. Lithos 206-207:201-213

Smith DC (1984) Coesite in clinopyroxene in the Caledonides. Nature 310:641-644

Smith DC, Dobrzhinetskaya LF, Godard G, Green HW (2011) Diamond-lonsdaleite-graphite relations examined by Raman mapping of carbon microinclusions inside zircon at Kumdy Kol, Kokchetav, Kazakhstan. In: Dobrzhinetskaya LF, Faryad SW, Wallis S, Cuthbert S (eds) Ultrahigh-pressure metamorphism:
25 years after the discovery of coesite and diamond. Elsevier, Oxford, pp 43-75

Sobolev NV, Fursenko BA, Goryainov SV, Shu J, Hemley RJ, Mao HK, Boyd FR (2000) Fossilized high pressure from the earth's deep interior: the coesite-in-diamond barometer. Proc Natl Acad Sci USA 97:11875-11879

Sutherland FL, Duroc-Danner JM, Meffre S (2008) Age and origin of gem corundum and zircon megacrysts from the Mercaderes-Rio Mayo area, South-West Colombia, South America. Ore Geol Rev 34:155-168

Trachenko K, Dove MT, Salje EKH (2002) Structural changes in zircon under $\alpha$-decay irradiation. Phys Rev B 65:180102

Váczi T (2014) A new, simple approximation for the deconvolution of instrumental broadening in spectroscopic band profiles. Appl Spectrosc 68:1274-1278

Váczi T, Nasdala L, Wirth R, Mehofer M, Libowitzky E, Häger T (2009) On the breakdown of zircon upon "dry" thermal annealing. Miner Petrol 97:129-138

van den Kerkhof AM, Olsen SN (1990) A natural example of superdense $\mathrm{CO}_{2}$ inclusions: microthermometry and Raman analysis. Geochim Cosmochim Acta 54:895-901

Wang W, Scarratt K, Emmett JL, Breeding CM, Douthit TR (2006) The effects of heat treatment on zircon inclusions in Madagascar sapphires. Gems Gemol 42:134-150

Wanthanachaisaeng B (2007) The influence of heat treatment on the phase relations in mineral growth systems. Dissertation, Johannes Gutenberg-Universität Mainz

Wanthanachaisaeng B, Häger T, Hofmeister W, Nasdala L (2006) Raman- und fluoreszenz-spektroskopische Eigenschaften von Zirkon-Einschlüssen in chrom-haltigen Korunden aus Ilakaka und deren Veränderung durch Hitzebehandlung. Gemmologie 55:119-132

Weber WJ, Ewing RC, Wang LM (1994) The radiation-induced crystalline-to-amorphous transition in zircon. J Mater Res 9:688-698

Wopenka B, Pasteris JD (1986) Limitations to quantitative analysis of fluid inclusions in geological samples by laser Raman microprobe spectroscopy. Appl Spectrosc 40:144-151

Wopenka B, Pasteris JD (1993) Structural characterization of kerogens to granulite-facies graphite: applicability of Raman microprobe spectroscopy. Am Mineral 78:533-557

Ye K, Liou J-B, Cong B, Maruyama S (2001) Overpressures induced by coesite-quartz transition in zircon. Am Mineral 86:1151-1155

Zhang Y (1998) Mechanical and phase equilibria in inclusion-host systems. Earth Planet Sci Lett 157:209-222

Zhang M, Salje EKH, Farnan I, Graeme-Barber A, Daniel P, Ewing RC, Clark AM, Leroux H (2000a) Metamictization of zircon: Raman spectroscopic study. J Phys Condens Matter 12:1915-1925

Zhang M, Salje EKH, Capitani GC, Leroux H, Clark AM, Schlüter J, Ewing RC (2000b) Annealing of O-decay damage in zircon: a Raman spectroscopy study. J Phys Condens Matter 12:3131-3148

Zhukov VP, Korsakov AV (2015) Evolution of host-inclusion systems: a visco-elastic model. J Metamorph Geol 33:815-828

Zwaan JCH, Buter E, Mertz-Kraus R, Kane RE (2015) The origin of Montana's alluvial sapphires. Gems Gemol 51(4):370-391 